\title{
Dinamika Penggunaan, Kebakaran, dan Upaya Restorasi Lahan Gambut: Studi Kasus di Desa Tanjung Leban, Bengkalis
}

\author{
Arifudin*1, Almasdi Syahza (iD) ${ }^{1}$, Osamu Kozan ${ }^{2}, K^{2 i}$ Mizuno² $^{2}$, Kosuke Mizuno², Zuli Laili Isnaini', \\ Wahyu Iskandar ${ }^{2}$, Sunawiruddin $\mathrm{Hadi}^{3}$, Asnawi $^{3}$, Ayu Aizatul Natasya ${ }^{3}$, Hasrullah $^{4}$
}

${ }^{1}$ Universitas Riau

${ }^{2}$ Kyoto University

${ }^{3}$ JICA Partnership Program

${ }^{4}$ Research Institute for Humanity and Nature

* arifudin@yahoo.com

\begin{abstract}
Abstrak. Pemanfaatan lahan gambut dalam kegiatan pertanian, terutama untuk perkebunan menjadi sorotan akhir-akhir ini, akibat terjadinya kebakaran lahan gambut sebagai penyebab bencana asap selama 18 tahun di Indonesia. Tulisan ini bertujuan menguraikan persoalan penggunaan lahan gambut, kejadian kebakaran, dan restorasi lahan gambut dari perspektif sosial ekonomi. Telah dilakukan penelitian dengan pendekatan studi kasus di Desa Tanjung Leban, Kecamatan Bandar Laksamana, Kabupaten Bengkalis, Provinsi Riau. Pengumpulan data dilakukan dengan cara wawancara terstruktur dan mendalam, FGD, dan observasi partisipatif dengan cara tinggal bersama masyarakat. Dari data yang dikumpulkan, dapat dikatakan bahwa persoalan lahan untuk pertanian adalah kompleks, terutama persoalan kepemilikan lahan oleh orang luar Desa. Masyarakat pada umumnya latah melakukan budidaya tanaman sawit, namun sayangnya lahan selalu terbakar secara berulang. Kemudian ada upaya kegiatan restorasi gambut, sebagai usaha pemulihan lahan gambut terdegradasi akibat kekeringan dan kebakaran. Akan tetapi kegiatan restorasi tidak mudah dilakukan, dimana masyarakat merasakan bahwa restorasi adalah pilihan yang baik untuk menghindari kebakaran lahan gambut berulang, namun mereka mempertanyakan keuntungan ekonomi langsung dan kendala teknis seperti banjir yang mengganggu tanaman sawit yang dibudidayakan. Dari studi kasus ini tetap menyisakan pertanyaan upaya strategis apa yag dapat dilakukan dalam kegiatan restorasi gambut guna mendukung pengelolaan lahan yang berkelanjutan
\end{abstract}

Kata Kunci: kebakaran, restorasi, dinamika penggunaan, dan lahan gambut

\section{PENDAHULUAN}

Rentetan kebakaran hutan dan lahan di Indonesia dekade terakhir telah menyita perhatian dunia, termasuk kebakaran gambut di sebagian besar wilayah di Provinsi Riau. Letaknya yang strategis, tidak hanya menjadikan Riau sebagai simpul ekonomi di wilayah barat Indonesia, namun juga menjadi sumber jerebu di Asia Tenggara. Sehingga pemanfaatan lahan gambut dalam kegiatan pertanian, terutama untuk perkebunan di Provinsi Riau, menjadi sorotan akhir-akhir ini, akibat terjadinya kebakaran lahan gambut sebagai penyebab bencana asap selama 18 tahun di Indonesia.

Kebakaran lahan gambut memang menjadi satu hal yang sangat kompleks karena terjadi dengan berbagai macam latar belakang persoalan, salah satunya adalah permasalahan kepemilikan lahan yang berhubungan pada pengelolaan dan penggunaan lahan gambut. Kepemilikan lahan yang didominasi oleh orang luar desa dan dikelola oleh para pekerja yang juga berasal dari luar desa menyebabkan kontrol pada lahan tidak optimal, sehingga kebakaran dapat terjadi sewaktu-waktu tanpa bisa dicegah lebih awal. Solusi komprehensip yang dipilih oleh pemerintah adalah restorasi lahan gambut. Dengan demikian menjadi menarik untuk melihat bagaimana dinamika penggunaan, kebakaran, dan restorasi lahan gambut, dengan mengambil studi kasus dimana program restorasi lahan gambut sudah mulai dijalankan.

\footnotetext{
To cite this article: Arifudin dkk. 2019. Dinamika Penggunaan, Kebakaran, dan Upaya Restorasi Lahan Gambut: Studi Kasus di Desa Tanjung Leban, Bengkalis. Unri Conference Series: Agriculture and Food Security 1: 40-45. https://doi.org/10.31258/unricsagr.1a6 


\section{KAJIAN PUSTAKA}

Lahan berkontribusi terhadap pendapatan rumah tangga petani melalui kegiatan usaha tani berbagai komoditas pertanian. Indikator tidak langsung tingkat pendapatan rumah tangga petani sebagai representasi tingkat kesejahteraan petani adalah distribusi pemilikan/penguasaan lahan yang diukur dengan indeks Gini. Menurut Nurmanaf (2001), di perdesaan berbasis pertanian, ketidakmerataan pendapatan rumah tangga berkaitan erat dengan ketidakmerataan penguasaan lahan pertanian. Ketimpangan penguasaan lahan merupakan salah satu faktor yang mendorong terjadinya ketimpangan distribusi pendapatan rumah tangga (Rachman et al., 2004). Sementara itu, pergeseran pemanfaatan lahan merupakan salah satu faktor penyebab pergeseran peran subsektor dalam struktur pendapatan rumah tangga (Purwoto et al., 2011; dan Susilowati et al., 2012).

Dinamika penguasaan lahan dapat dilihat dari perubahan struktur pengusaan lahan pertanian. Secara makro, menunjukkan telah terjadi perubahan struktur penguasaan lahan oleh rumah tangga pertanian, yaitu makin bertambahnya jumlah petani gurem dengan luas penguasaan yang makin kecil, dan di sisi lain terjadinya pengumpulan penguasaan lahan pada sebagian kecil rumah tangga berlahan luas (Sumaryanto dan Rusastra, 2000). Semakin timpangnya struktur penguasaan lahan mengindikasikan semakin timpangnya struktur pendapatan masyarakat pedesaan, karena petani lahan luas semakin memperoleh nilai tambah dan akumulasi modal sehingga dapat melakukan perluasan usaha baik pada usaha tani maupun usaha nonpertanian.

Penggunaan lahan sesungguhnya merupakan upaya manusia dalam interaksinya dengan sumberdaya fisik lahan dalam rangka memenuhi kebutuhan hidupnya (Utoyo, 2012). Perubahan struktur penggunaan lahan bukanlah semata-mata fenomona fisik berkurangnya luasan lahan tertentu dan meningkatnya penggunaan lahan untuk penggunaan lainnya, melainkan mempunyai kaitan erat dengan perubahan orientasi ekonomi, sosial, budaya, dan politik masyarakat. Begitu juga dengan lahan gambut, sebagai lahan marginal dimanfaatkan tersebab adanya kebutuhan pengembangan pembangunan perkebunan, baik oleh korporasi maupun masyarakat, dan akhirnya membawa bencana kebakaran lahan gambut di Indonesia sebagai penyebab bencana asap.

Tahun 2015 menjadi salah satu tahun terburuk bencana asap bagi Indonesia. Setidaknya lebih dari 43 juta jiwa terpapar kabut asap di Pulau Sumatera dan Kalimantan. Data yang dihimpun dari Badan Nasional Penanggulangan Bencana (BNPB), World Resources Institute, Center for International Forestry Research, Global Fire Emissions Database dan National Aeronautics and Space Administration (NASA) menunjukkan sebanyak 505.527 jiwa terinfeksi penyakit saluran pernafasan, terdapat 115.940 titik api terbanyak semenjak tahun 2003, dan lebih dari 22.000 personel gabungan diturunkan untuk memadamkan api di lapangan. Lebih mencengangkan lagi, 99\% kebakaran lahan disebabkan oleh aktifitas manusia. Data lain milik Badan Nasional Penanggulangan Bencana (BNPB) dan Lembaga Penerbangan dan Antariksa Nasional (LAPAN) menyebutkan lebih dari 800.000 hektar hutan dan lahan terbakar di Sumatera yang dihitung dari 1 Juli hingga 20 Oktober 2015.

Berdasarkan laporan Bank Dunia Tahun 2016, kebakaran lahan terjadi dengan luas 2.426,21 Ha. Sekitar 505,887 Ha terjadi di areal konsesi kelapa sawit; 233,414 Ha di areal konsesi HTI; 176,179 Ha di areal hutan rawa gambut; 259,376 Ha di hutan alam; 807,369 ha di areal penggunaan lain; 24,183 Ha di kawasan pertambangan; 346,039 $\mathrm{Ha}$ di areal tanaman pangan; dan 72,763 Ha di areal tanaman perkebunan. Total kerugian dan kerusakan yang ditimbulkan dari kebakaran lahan dan bencana kabut asap tersebut diperkirakan sebesar USD 16,124 Juta untuk seluruh Indonesia dan sebesar USD 1,373 Juta untuk Provinsi Riau.

Ada banyak faktor yang menyebabkan kebakaran hutan tersebut, setidakya terdapat tujuh penyebab kebakaran lahan gambut yakni: (1) cuaca yang ekstrim; (2) lahan gambut yg mudah terbakar; (3) cara bercocok tanam masyarakat dengan cara membakar; (4) tindakan membakar secara meluas, motif finansial; (5) tidak optimalnya pencegahan oleh aparat di tingkat bawah; (6) kurang cepat \& efektifnya pamadaman api; dan (7) penegakan hukum yg tidak bisa menyentuh dalang pelaku pembakaran (Zainal, 2015). Saat ini semakin jelas bahwa penyebab utama kebakaran hutan dan lahan akibat kesalahan dalam pengelolaan lahan gambut, yang terlanjur dikeringkan, sehingga menjadi bahan yang mudah terbakar. Oleh karena itu restorasi lahan gambut menjadi prioritas program pengurangan emisi dan juga sekaligus mengembalikan fungsi ekologis lahan gambut.

Pemerintah telah mengeluarkan Peraturan Presiden Nomor 1 Tahun 2016 tentang Badan Restorasi Gambut (BRG). Tugas pokok dan fungsi utama BRG adalah pelaksanaan koordinasi dan penguatan kebijakan pelaksanaan restorasi gambut seluas 2 juta hektar pada tahun 2016 - 2020. Untuk mencapai tujuan 
dalam pengembalian, pemulihan dan perbaikan gambut di indonesia, BRG menjalankan tugas tersebut dengan 3 hal pokok kegiatan restorasi gambut yaitu pembasahan kembali (rewetting), penanaman kembali (Revegetation), dan Revitalisasi ekonomi (Revitalization) atau lebih dikenal dengan nama 3R.

\section{METODE}

Penelitian ini dilakukan di Desa Tanjung Leban Kecamatan Bandar Laksamana Kabupaten Bengkalis Propinsi Riau. Penelitian dilakukan pada bulan Januari - Juni 2018. Pengumpulan data dan informasi dari responden dilakukan dengan cara wawancara terstruktur dan mendalam, focus group discussion, dan observasi partisipatif dengan cara tinggal bersama masyarakat. Informan dalam penelitian ini adalah masyarakat yang memiliki lahan gambut, dan berada pada Kawasan sepanjang kanal yang berpotensi untuk bergabung dalam kegiatan restorasi lahan gambut. Data diolah dengan analisis deskriptif kualitatif, melalui proses reduksi data, penyajian, dan pengambilan simpulan-simpulan, serta analisis spasial sederhana berdasarkan hasil wawancara dan ground check ke setiap lahan.

\section{HASIL DAN PEMBAHASAN}

\section{Kebakaran Lahan dan Restorasi Lahan Gambut}

Kebiasaan masyarakat membuka lahan dengan cara membakar merupakan salah satu pemicu terjadinya kebakaran lahan gambut yang meluas. Hal ini dapat dilihat dari hasil wawancara dengan masyarakat. Dari 61 Responden yang ditanya, 69\% mengaku membuka lahan dengan cara tebas kemudian lalu dibakar. Tebas bakar disini adalah kegiatan menebas semak belukar dan pohon kayu yang ada terlebih dahulu, setelah kering kemudian dibakar.

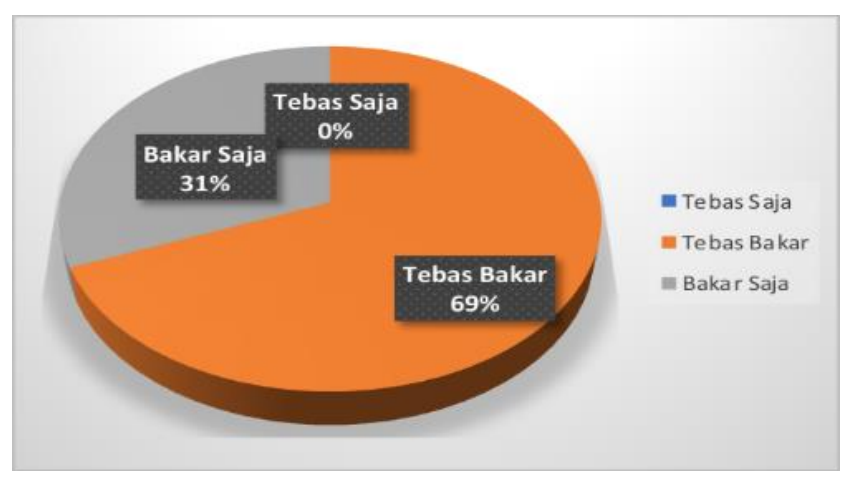

Gambar 1. Cara Pengolahan Lahan Oleh Masyarakat Desa Tanjung Leban

Di desa Tanjung Leban, masyarakat mulai membuka lahan diperkirakan bermula pada tahun 1992. Pola pembukaan dan pembersihan lahan yang dilakukan pada saat itu adalah dengan cara membakar. Periode pembukaan lahan yang dilakukan oleh masyarakat di desa tanjung leban dapat terlihat seperti gambar berikut.

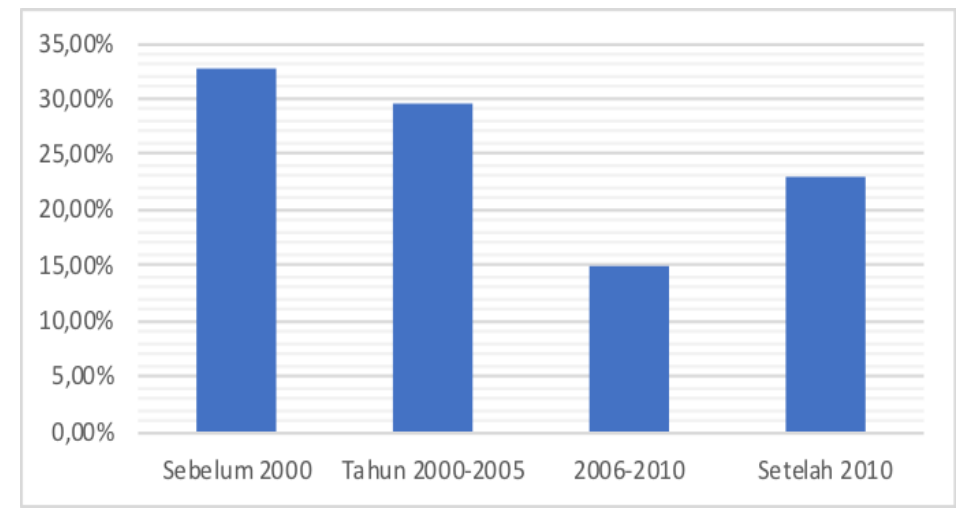

Gambar 2. Periode Pembukaan Lahan di Desa Tanjung Leban

Sekitar 32,8 \% pembukaan lahan dilakukan pada sebelum tahun 2000, sedangkan pebukaan lahan setelah tahun 2010 adalah sebesar 23\%. Pembukaan lahan setelah tahun 2010 ini merupakan periode dimana kejadian kebakaran lahan sangat marak sekali terjadi dan pada tahun 2013-2014, terjadi kebakaran lahan 
gambut dengan luas mencapai ratusan hektar. Khusus kebakaran di Dusun Bakti Desa Tanjung Leban kebakaran terjadi sebelum tahun 2013. Namun demikian, kejadian kebakaran tidak hanya berhenti, pada tahun 2015, hingga saat ini masih terjadi kebakaran lahan gambut.

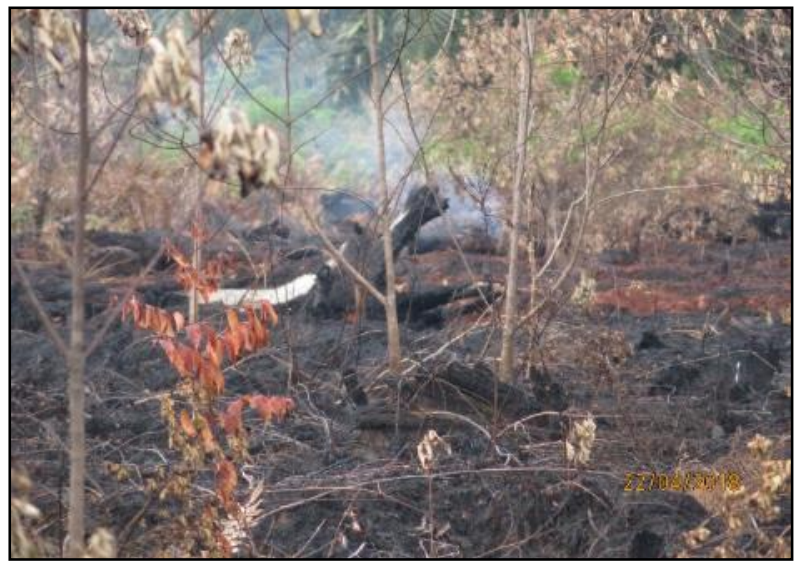

Gambar 3. Kebakaran Lahan di Dusun Bakti Desa Tanjung Leban Tahun 2018

Saat ini, masyarakat Desa Tanjung Leban umumnya sudah mengetahui tentang peraturan larangan membakar lahan. Mereka mendapat informasi tentang larangan membakar lahan dari sosialisasi yang dilakukan oleh Masyarakat Peduli Api (MPA), Kepolisian, Pemadam Kebakaran, dan aparat desa yang juga selalu berpatroli dimusim kemarau.

Upaya restorasi juga telah dilakukan oleh berbagai pihak, yang meliputi kegiatan pembuatan sekat kanal, sebagai upaya pembasahan kembali, kegiatan penanama kembali dengan tanaman ekosistem gambut dan kegiatan peningkatan ekonomi masyarakat. Kegiatan penanaman kembali lahan bekas terbakar dengan berbagai macam tanaman pohon asli ekosistem rawa gambut, seperti Bintangur, Meranti Bakau, Jelutung sudah dilakukan di Desa Tanjung Leban. Bahkan Desa Tanjung Leban, menjadi laboratorium lapangan berbagai pihak, seperti CIFOR, WWF, NASA, dan terutama kampus Universitas Riau untuk dalam melakukan kegiatan restorasi gambut, sebagai model pelaksanaan restorasi lahan gambut di Indonesia. Sehingga masyarakat di Desa Tanjung Leban memiliki contoh nyata bahwa kegiatan restorasi lahan gambut itu dapat dilakukan oleh masyarakat. Sebagian masyarakat juga masih mengeluhkan, keuntungan ekonomi langsung dari kegiatan restorasi gambut yang dialakukan. Sebab pada umumnya tanaman yang dibudidayakan adalah tanaman kayu, bahkan sebagai warga mempersepsikan kegiatan restorasi gambut sebagai program "menanam kayu"di lahan warga. Keluhan lain yang muncul adalah bagi sebagian yang sudah terlanjur menanam sawit, jika terjadi hujan lebat, maka tanah mereka tergenang sebab adanya pembangunan sekat kanal. Namun setelah desain sekat kanan dibangun berpintu, dengan maksud untuk mempermudah melepaskan air saat air melimpah, mereka memaklumi dan mendukung kegiatan restorasi lahan gambut.

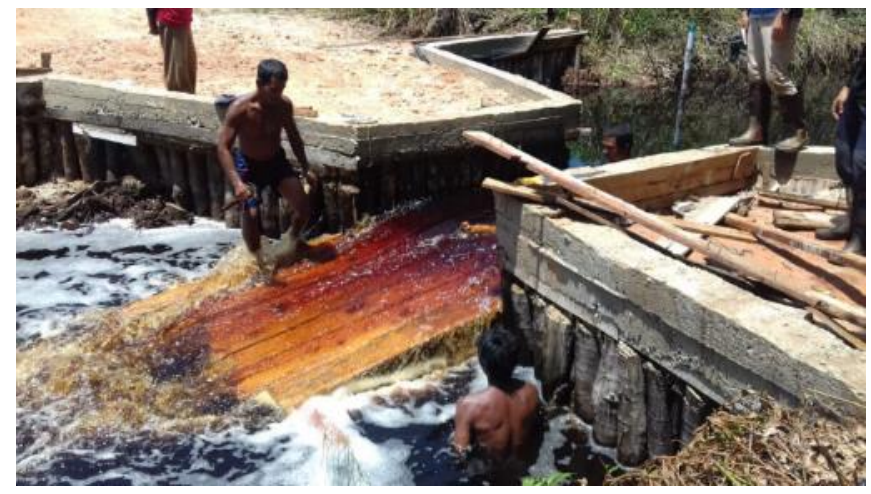

Gambar 4. Contoh kegiatan pembuatan sekat kanal untuk rewetting

\section{Dinamika Penggunaan Lahan}

Pembukaan lahan di Tanjung Leban oleh masyarakat dilakukan pada tahun 1992 dengan komoditas utama yang ditanam adalah karet. Sejarah pembukaan lahan di Desa Tanjung Leban, diawali oleh Perusahaan Hutan Tanaman Industri (HTI). Setelah terbuka akses, masyarakat kemudian menguasai lahan, disebabkan 
adanya kesempatan, dan kecemburuan, ketika masyarakat tidak lagi memiliki lahan di wilayah mereka, namun setelah mereka memiliki lahan, lahan jatah yang diperolah, akhirnya djual ke orang lain yang pada umumnya tidak berdomisi di Desa Tanjung Leban.

"Awalnya lahan-lahan yang ada diperbatas perusahaan itu dikuasai oleh perusahaan, dan orang-orang perusahaan, masyarakatpun mulai menuntut hak, dan dilakukan pembagian lahan kepada masyarakat melalui kelompok-kelompok", tapi sekarang lahan tu dah dijual lagi samo orang lain, tinggal satu duo ajo yang dimiliki orang Tanjung Leban (Male, wawancara-Februari 2018)

Perkebunan karet masyarakat berkembang dengan baik dan menjadi sumber perekonomian utama dalam pemenuhan kebutuhan hidup. Namun demikian, eksistensi perkebunan karet mulai tergerus setelah harga karet mengalami fluktuasi. Harga karet yang terus anjlok membuat masyarakat harus mencari jalan lain untuk tetap bertahan dalam memenuhi kebutuhan hidupnya. Fenomena ini kemudian menjadi salah satu penyebab masyarakat mengkonversi perkebunan karet menjadi perkebunan kelapa sawit.

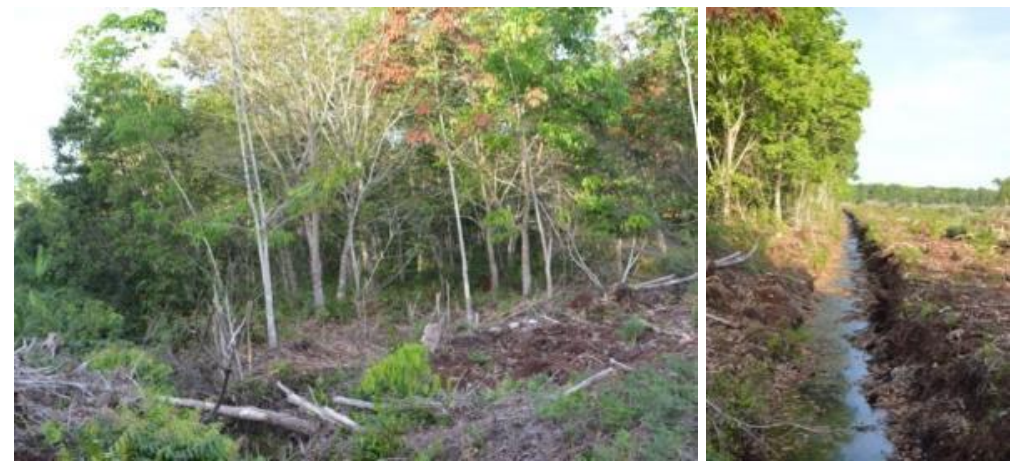

Gambar 5. Kondisi Lahan kebun karet masyarakat yang ditebang

Kelapa sawit menjadi primadona yang diminati oleh masyarakat yang latah untuk menanam sawit. Perubahan struktur penggunaan lahan dari perkebunan karet menjadi perkebunan sawit terjadi dengan cepat, walaupun tidak semua lahan perkebunan karet diubah menjadi perkebunan sawit. Sampai saat ini masih terdapat beberapa perkebunan karet, namun sebagian besar tidak dipanen lagi sebab harga karet yang sangat rendah.

Perubahan penggunaan lahan tersebut merupakan cerminan upaya dan interaksi masyarakat dalam memanfaatkan dan mengelola semberdaya alam beserta kondisi lingkungan yang menyertainya. Fenomena tersebut pada gilirannya akan berakibat pada mutu lingkungan hidup dan nilai lahan yang ada. Menurut Utoyo (2012), Penggunaan lahan juga merupakan refleksi struktur perekonomian dan preferensi masyarakat. Struktur perekonomian dan preferensi masyarakat ini bersifat dinamis yang orientasinya selalu berubah setiap saat sejalan dengan pertumbuhan penduduk dan dinamika pembangunan, maka dari itu struktur penggunaan lahanpun bersifat dinamis dan dengan dengan demikian perubahan pola penggunaan lahan tidak dapat terhindarkan.

Kondisi perubahan struktur penggunaan lahan dari perkebunan karet menjadi perkebunan kelapa sawit ternyata tidak menjadi alternatif yang cukup baik bagi masyarakat di Desa Tanjung Leban. Lahan-lahan yang ditanami sawit merupakan lahan gambut yang cukup dalam sehingga masalah baru kembali muncul dan menjadi momok bagi masyarakat. Lahan gambut yang telah ditanami sawit mengalami kekeringan dan sangat mudah terbakar. Pasca kebakaran, beberapa warga tidak lagi menggarap lahan mereka dan masih terbiarkan menjadi lahan-lahan tidur sampai saat ini. Berkaitan dengan kebakaran lahan yang terjadi dan lahan-lahan yang telah dibiarkan karena adanya trauma kebakaran menyebabkan banyak masyarakat menjual lahannya kepada orang-orang yang berasal dari luar desa.

Fenomena penjualan lahan oleh masyarakat Desa Tanjung Leban sangat marak sekali terjadi, lahan dijual kepada para pemilik modal yang sebagian besar berasal dari luar desa seperti dari Dumai, Bengkalis, Pekanbaru, dan bahkan dari Medan. Kondisi ini terus berlanjut sehingga menyebabkan kepemilikan lahan di Desa Tanjung Leban di dominasi oleh orang-orang yang berasal dari luar desa. 

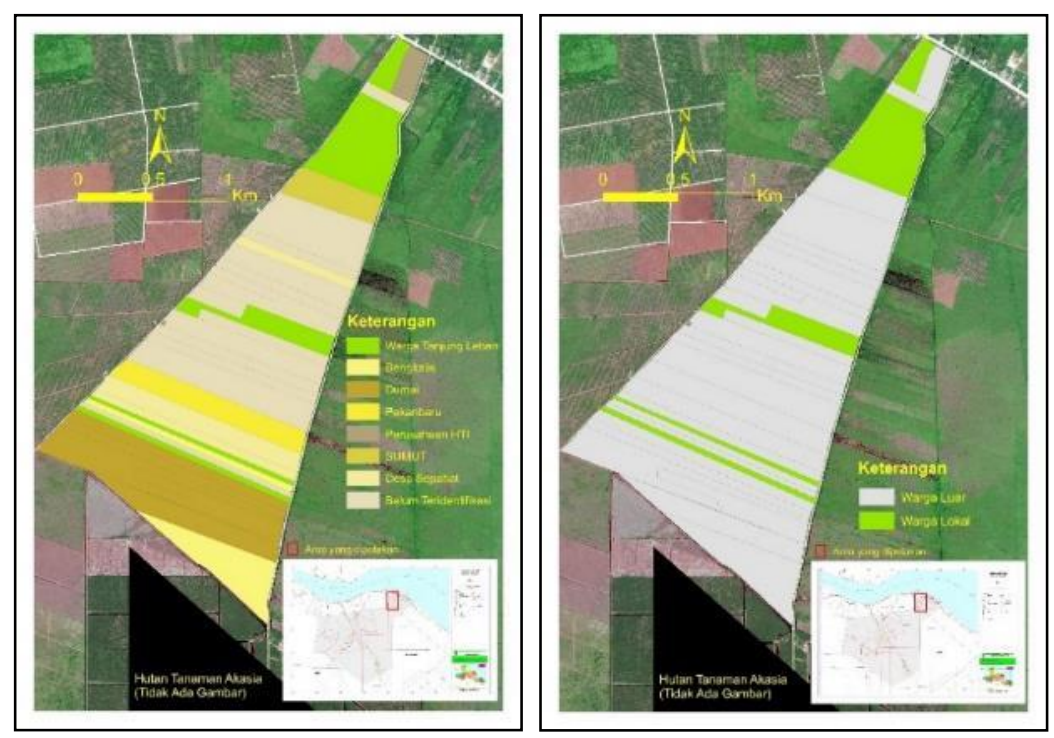

Gambar 6. Kepemilikan Lahan oleh Warga Lokal dan Orang Luar Desa

\section{KESIMPULAN}

1. Dinamika penggunaan lahan gambut adalah sangat kompleks, sebab persoalan kepentingan ekonomi dan terutama kepemilikan lahan, yang tidak lagi dimiliki oleh warga tempatan.

2. Masyarakat merasakan bahwa restorasi adalah pilihan yang baik untuk menghindari kebakaran lahan gambut yang selalu berulang, namun mereka mempertanyakan keuntungan ekonomi langsung dan kendala teknis seperti banjir yang menganggu tanaman sawit yang terlanjur telah dibudidayakan.

3. Dari studi kasus ini tetap menyisakan pertanyaan, upaya strategis apa yag dapat dilakukan dalam kegiatan restorasi gambut guna mendukung pengelolaan lahan yang berkelanjutan.

\section{DAFTAR PUSTAKA}

Badan Restorasi Gambut. 2016. Rencana Strategis Badan Restorasi Gambut 2016-2020. P.5 /KB BRG-SB/11/2016. Jakarta.

Nurmanaf, A.R. 2001. An Analysis of Economic Inequalities between Household in Rural Indonesia. Dissertation Findings in Brief. Faculty of Business and Computing, Southern Cross University, Coffs Harbour Campus. Australia.

Peraturan Presiden Nomor 1 Tahun 2016 tentang Badan Restorasi Gambut (BRG).

Purwoto, A., I.W. Rusastra, B. Winarso, T.B. Purwantini, A.K. Zakaria, T. Nurasa, D. Hidayat, C. Muslim, dan C.B. Adawiyah. 2011. Panel Petani Nasional (Patanas): Indikator Pembangunan Pertanian dan Perdesaan di Wilayah Agroekosistem Lahan Kering Berbasis Sayuran dan Palawija. Laporan Penelitian. Pusat Sosial Ekonomi dan Kebijakan Pertanian. Bogor.

Rachman, H.P.S., Supriyati, Saptana, dan B. Rachman. 2004. Struktur dan Distribusi Pendapatan Rumah Tangga Petani Lahan Sawah: 50-90. Dalam H.P. Saliem, E.

Sumaryanto, dan I.W. Rusastra. 2000. Struktur Penguasaan Tanah dan Hubungannya dengan Kesejahteraan Petani. Prospektif Pembangunan Pertanian dan Pedesaan dalam Era Otonomi Daerah. Bogor: Pusat Penelitian Sosial Ekonomi Pertanian.

Susilowati, S.H., T.B. Purwantini, D. Hidayat, M. Maulana, A.M. Ar-Rozi, R.D. Yofa, Supriyati, dan W.K. Sejati. 2012. Panel Petani Nasional (Patanas): Dinamika Indikator Pembangunan Pertanian dan Perdesaan di Wilayah Agroekosistem Lahan Kering Berbasis Perkebunan. Laporan Penelitian. Pusat Analisis Sosial Ekonomi dan Kebijakan Pertanian. Bogor.

Utoyo, B. 2012. Dinamika Penggunaan Lahan di Wilayah Perkotaan (Studi di Kota Bandar Lampung). Seminar HasilHasil Penelitian dan Pengabdian Kepada Masyarakat - Dies Natalis FISIP Universitas Lampung.

Zainal. 2015. Akar Permasalahan Kebakaran Hutan Serta Solusi Dalam Penyelesaiannya (Studi Kasus Provinsi Riau). Prosiding Seminar Nasional Prodi Ilmu Pemerintahan Fisip Unikom: 258-277. 